Article

\title{
Structure and Regeneration Patterns of Pinus nigra subsp. salzmannii Natural Forests: A Basic Knowledge for Adaptive Management in a Changing Climate
}

\author{
Pedro A. Tíscar ${ }^{1, *}$ and Juan C. Linares ${ }^{2}$
}

1 Centro de Capacitación y Experimentación Forestal, Cazorla 23470, Spain

2 Departamento de Sistemas Físicos, Químicos y Naturales, Universidad Pablo de Olavide, Ctra. de Utrera km 1, Sevilla 41002, Spain; E-Mail: jclincal@upo.es

* Author to whom correspondence should be addressed; E-Mail: pedroa.tiscar@juntadeandalucia.es; Tel.: +34-953-711621; Fax: +34-953-727066.

Received: 12 September 2011; in revised form: 17 October 2011 / Accepted: 2 December 2011 / Published: 9 December 2011

\begin{abstract}
Since climate change projections contain many uncertainties and are normally unable to predict the direction and magnitude of change at the small scale needed by forest managers, some understanding about the functioning of the target forest should be obtained before a robust management strategy can be applied. Structure and regeneration patterns are related to key ecosystem processes which, on the other hand, can be modified by silvicultural treatments. In this research, the structure and recruitment dynamics of two stands with different histories of management were investigated in the southern limit of the range of Pinus nigra subsp. salzmannii (Southeast Spain). We described forest structure and facilitation effects by forest canopies and nurse shrubs, and quantified the processes affecting each stage of regeneration (dispersed seed, first year seedling and second year seedling) in different microhabitats. Forest structure was more complex in the stand scarcely influenced by human activities. Juniperus communis shrubs seemed to facilitate the establishment of tree saplings. Most seedlings died of desiccation during their first summer. At best, 190 out of 10,000 emerged seedlings survived the first summer. In light of these results, the possibilities of applying close-to-nature forestry in the study forests and other aspects of silviculture under a frame of adaptive forest management are discussed.
\end{abstract}


Keywords: Mediterranean ecosystems; forest structure; recruitment dynamics; plant demography; transition probability; facilitation; close-to-nature forestry

\section{Introduction}

Most forest ecosystems have already been destroyed, fragmented or degraded, and are being threatened by ongoing climate change that will continue in the coming decades [1]. Models of climate change delineate a general scenario of progressively increasing temperatures and altered rainfall patterns [2], but are normally unable to predict the direction and magnitude of change at the smaller scales needed by forest managers [3]. This poor resolution is more evident in mountainous regions, where precipitation amount and patterns are strongly determined by local geomorphology [4], and small climatic refugia may support rare species assemblages which are not adapted to the regional climate [5,6]. Function can also vary over short distances in mountains. For instance, growth trends in the long-term, decline processes, biotic interactions and patterns of tree regeneration are highly variable in Mediterranean mountains due to local and regional scale differences in microclimatic conditions, soil properties, land-use history and stand structure [7-11]. Under such uncertain and variable conditions, measures proposed to adapt forest management to climate change would be better addressed if they were based on knowledge of the structure and function of the target forests, and applied in a framework of adaptive management, i.e., the capacity of learning from experience and iteratively incorporating lessons into future plans $[3,5]$.

One consequence of the intrinsic environmental heterogeneity of Mediterranean mountains is that demographic rates of plant species are expected to vary spatially as much as those factors affecting recruitment dynamics do $[7,8,11]$. Thus, all forest-stands within a large area might experience common influences caused by the weather, but there might be stand-specific differences caused by local conditions unique to every stand, such as topography or disturbance level. At smaller spatial scales, heterogeneity can emerge within forest-stands as the result of variation in microclimate, much of which is generated by organisms $[8,12,13]$. For instance, it is well documented that shade provided by tree canopies and shrubs offers protection against temperature extremes and excessive evapotranspiration, facilitating the establishment of tree seedlings [14,15]. This plant-plant interaction of facilitation can be particularly important for the permanence of Mediterranean forests, because most seedlings emerged under Mediterranean conditions die of desiccation within their first years of life $[8,11,16]$, and rising temperatures and a decrease in rainfall due to climate change will magnify the risk of drought in Mediterranean areas [17].

The management of canopy cover, and the subsequent change in the amount of light transmitted onto the forest floor, is a current silvicultural practice carried out in order to control understory shrubs and/or the establishment of desired tree regenerates [18]. In this respect, the application of sound silvicultural treatments will be equally essential to create a regeneration niche for Mediterranean tree species in the coming decades, but it is necessary to identify the part of the life cycle that is most likely to prevent natural regeneration in a successively drier environment. 
Among the silvicultural actions proposed to adapt forest management to climate change, the possibility of restoring forests to their historic natural conditions is an alternative frequently quoted, for which reconstructive studies of old-growth forests are particularly useful [19,20]. It can be argued that old-growth forests (i.e., forests with a small degree of human disturbance, composed of native species in a late successional condition and trees of all age-classes) are adapted to past climatic conditions and do not offer a robust benchmark to guide forest management under future climate scenarios. Yet, ecological information obtained in old-growth forests constitutes a valuable resource to implement adaptive management in currently managed forests. Firstly, plantations and other forest structures resulting from forest management are more vulnerable to disturbance (fire, pest outbreaks, storm winds) than natural structures [21-23], and some sort of natural reference conditions would be necessary to guide the practice of silviculture even before concerns about climate change were made [24]. Secondly, old-growth stands might help to a better understanding of the effects produced by climate change on sites where key ecological processes have been altered by silvicultural management. Ecological processes are part of the biological diversity that underpins forest resilience to disturbance [5]. Finally, old-growth forests have proved to be resistant and resilient to past climate stresses. For instance, several dendrochronological studies show that present forests of Pinus nigra Arn. subsp. salzmannii Dunal (Franco) (Pinus nigra hereafter) had to cope with frequent episodes of severe drought over the last 500 years [25].

In this article, we investigate the effects of forest canopy and shrub cover on the regeneration process of Pinus nigra (Figure 1). This pine dominates mid-altitude forests from the eastern calcareous mountains of Spain, where it has been traditionally favored over broad-leaved tree species (Quercus ilex L., Q. faginea Lam., Acer granatensis Boiss.). Berberis hispanica Boiss. \& Reut., Crataegus monogyna Jacq., Rosa sp., Lavandula latifolia Medik., Echinospartum boissieri (Spach) Rothm. and Juniperus communis L., the latter in sites of degraded soils, are common shrubs in the understory. At high altitudes, Pinus nigra forms monospecific, open forests with a dense understory of Juniperus communis and Erinacea anthyllis Link. The specific aim of this study was to analyze structure and regeneration patterns in two forests of Pinus nigra with different environmental conditions and history of management. To do so, the effects of forest canopy and shrub cover were considered. This information was then used to make some silvicultural recommendations to deal with uncertainty in the face of climate change. The research was carried out at the southern margin of Pinus nigra distribution area (SE Spain), in forests that are perhaps among the most vulnerable for the loss of tree species due to climate change [26]. 
Figure 1. (left) Geographical distribution of Pinus nigra subsp. salzmannii in Spain (dark areas). Cazorla, Segura and Las Villas Natural Park is located within the rectangle in the southeast of the country; (right) Detail of the distribution of Pinus nigra ssp. salzmannii in the Natural Park with indication of the two study forests CE (Cañada del Espino), PT (Puertollano).

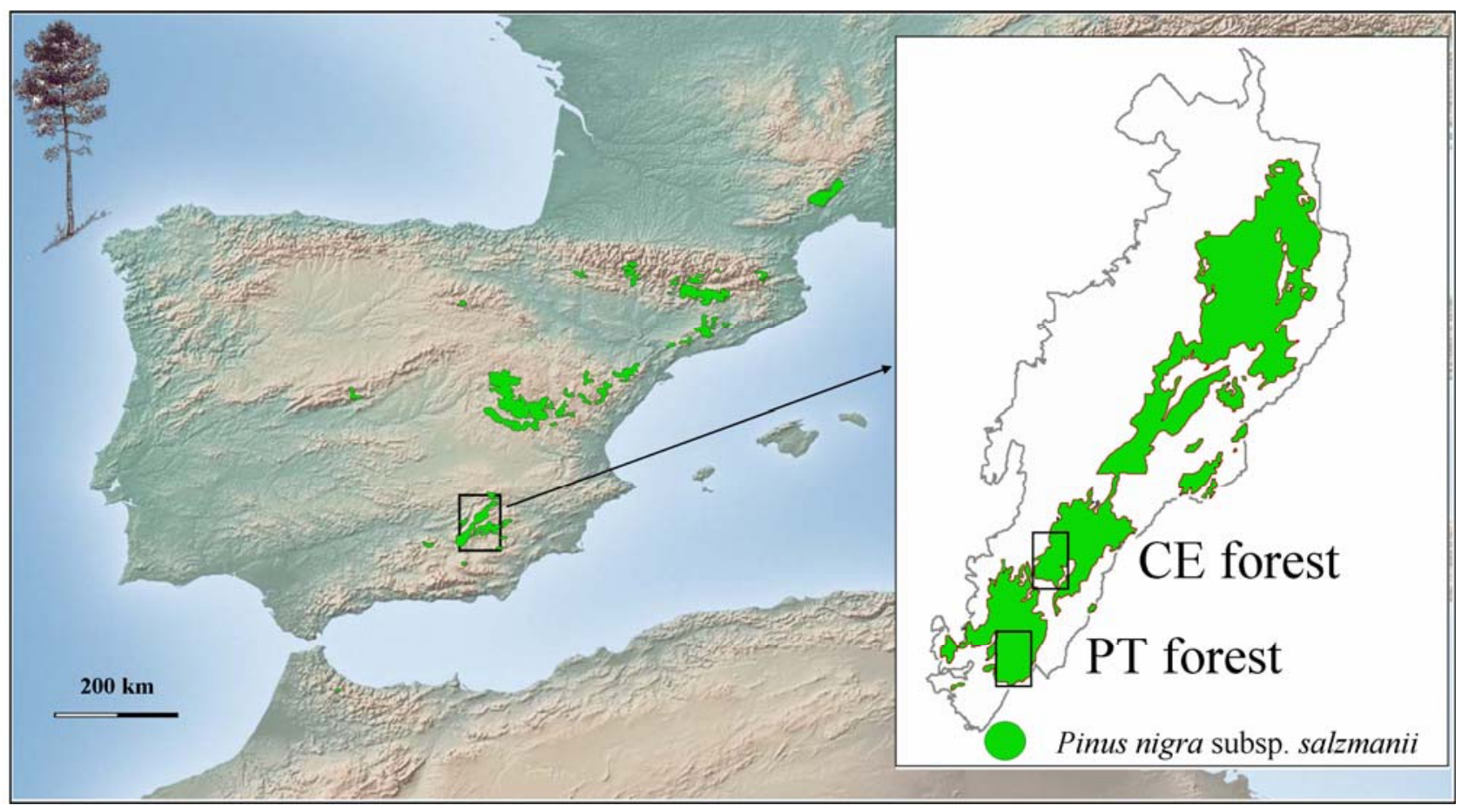

\section{Materials and Methods}

\subsection{Species and Site Descriptions}

Pinus nigra covers 405,983 hectares of pure stands along the eastern calcareous mountains of Spain [27]. The species shows some evolutionary traits: height at maturity (up to $50 \mathrm{~m}$ ), longevity ( $>600$ years), dispersal season (late winter), thick bark, late flowering and absence of serotinous cones, which indicate that current Pinus nigra forests did not evolve under an environment of frequent crown fires [28]. Seed predation, herbivory by ungulates, the presence of vegetation litter, unsuitable meteorological conditions and the irregular production of seed crops are factors which negatively affect Pinus nigra regeneration in natural stands [24,29]. This study was carried out during the year 2000 at the southern extreme of Sierras de Cazorla, Segura and Las Villas Natural Park (Southeast Spain, Figure 1) in two of the southern-most natural forests of Pinus nigra: Cañada del Espino and Puertollano, which are approximately $10 \mathrm{~km}$ apart. Cañada del Espino (ca. $186.43 \mathrm{ha}$ ) coincides with one of the management units in which a larger forest was divided to implement harvest operations over the 20th century. It was chosen to be representative of Pinus nigra forests that have been regularly managed. It is located in a small valley at $\sim 1,450 \mathrm{~m}$ a.s.1. and exhibits a continuous canopy with small openings and gaps of different size. Puertollano (ca. 42 ha) is an open canopy forest-stand that has been scarcely influenced by human activities, located at $\sim 1,850 \mathrm{~m}$ a.s.l. in a mountain pass. Both forests have a Mediterranean type climate. Snowfalls and frost are common during the winter, but 
summers are dry and hot. According to data from a nearby meteorological station, the average rainfall in Cañada del Espino is $1,075 \mathrm{~mm}$, of which $55 \mathrm{~mm}$ occur during the summer, and mean monthly temperatures range from $5.1{ }^{\circ} \mathrm{C}$ in February to $22.3{ }^{\circ} \mathrm{C}$ in August. Rainfall values are expected to be higher and temperature values lower in Puertollano, according to regression analysis of meteorological data [4]. Soils are leptosols (rendzinas) with frequent rocky outcrops on higher slopes and luvisols on less steep terrain with alluvial deposits [30].

\subsection{Structural Analysis}

Forest structure was characterized by means of a forest inventory that consisted of the systematic sampling of circular plots distributed on a square grid in the two study forests. Eight $17.84 \mathrm{~m}$ radius plots $\left(1,000 \mathrm{~m}^{2}\right.$ in area, approximately one plot every $5 \mathrm{ha}$ ) were established in Puertollano, whilst twenty $13-\mathrm{m}$ radius plots $\left(531 \mathrm{~m}^{2}\right.$ in area, approximately one plot every 9 ha) were distributed within Cañada del Espino. Plot radius and sampling effort differed between forests because of differences in tree density and amount of variation amongst sampling units. Within the plots, diameter at breast height (dbh, $1.3 \mathrm{~m}$ ) was measured in every tree over $1.3 \mathrm{~m}$ high and its species identity was noted. The composition of the woody shrub layer was determined, and the cover of each species (\% area occupied by the vertical projection of the whole foliage) measured along two line intercept transects that coincided with two perpendicular diameters in the sampled plot.

For each sampling plot, we calculated a coefficient of variation to evaluate dbh differentiation $(\mathrm{CV}=\mathrm{SD} / \mathrm{mean})$ and the number of large trees. The following scale was used to classify dbh differentiation: $\mathrm{CV}<0.05$ : very low differentiation, $0.05<\mathrm{CV}<0.15$ : low differentiation, $0.15<\mathrm{CV}<0.30$ : moderate differentiation, $0.30<\mathrm{CV}<0.60$ : high differentiation and $\mathrm{CV}>0.60$ : very high differentiation. CVs, as an estimate of dbh differentiation, and the number of trees exceeding a threshold diameter are useful to describe forest structure and its relationship with ecosystem function [31]. We determined $50 \mathrm{~cm}$ as the dbh threshold above which Pinus nigra individuals would be considered large trees. It has been argued that thresholds should be established on some sort of ecological basis. In this case, a $50 \mathrm{~cm}$ dbh represents the average size of mature trees that begin to develop the architectural elements found in veteran trees, such as decurrent branches and maximum height [32].

\subsection{Regeneration Patterns}

We studied both the influence of shrubs on Pinus nigra regeneration at Puertollano forest, and Pinus nigra recruitment dynamics at Cañada del Espino forest. In this latter study site, shrub cover was mostly composed of pioneer species that dominated in large gaps (Table 1), but was negligible inside forested areas, so we did not consider any influence of shrubs on Pinus nigra regeneration here.

In order to study recruitment dynamics, the spatial distribution of pineseeds after dispersal was sampled by means of seed-collecting traps (two $24 \times 31 \times 5 \mathrm{~cm}$ aluminium pans protected with a wire mesh to prevent seed removal by birds or rodents) that were nailed to the ground. No evidence was found of ants or other small animals removing pineseeds from the traps. We selected three stands roughly $1 \mathrm{~km}$ apart (replicates). For each stand, we used 18 traps that were evenly distributed amongst the three commonest microhabitats in this forest: gap ( $0 \%$ canopy cover), clear forest (40-60\% canopy 
cover) and dense forest (canopy cover $>80 \%$ ). Traps were checked regularly during the dispersal season and the viability of the collected pineseeds checked in a growth chamber.

Table 1. Shrub cover in the two study forests.

\begin{tabular}{lclc}
\hline \multicolumn{2}{c}{ Cañada del Espino forest } & \multicolumn{2}{c}{ Puertollano forest } \\
\hline Species & Cover (\%) & Species & Cover (\%) \\
\hline Thymus sp. & 6.8 & Juniperus communis & 20.3 \\
Rosa sp. & 0.6 & Erinacea anthyllis & 19.3 \\
Lavandula latifolia & 6.0 & Berberis hispanica & 14.7 \\
Berberis hispanica & 0.4 & Teucrium poleum & 6.3 \\
Echinospartum boissieri & 4.0 & Rosa sp. & 1.1 \\
All shrubs & 19.5 & All shrubs & 64.2 \\
\hline
\end{tabular}

The effect of microhabitat on seed predation was examined by depositing six pineseeds (the mean density of seeds dispersed onto the ground at that moment) in one Petri dish that was open to predators and placed next to every seed-collecting trap (54 Petri dishes in total). The experiment was set up once dispersal had ended and predation checked periodically until seedling emergence was completed. Seedling emergence and survival during the first year were followed by periodic surveys in $25 \times 25 \mathrm{~cm}$ permanent sampling plots, established beside each seed-collecting trap. The number of live and dead seedlings and the cause of death, if they died, were recorded in each survey.

Transition probabilities were then calculated to identify the most influential factors in Pinus nigra recruitment dynamics. Recruitment is a multiphase process involving several sequential life-history stages that are connected by a number of processes, affected by factors and with specific transition probabilities $[8,11,16]$. The experimental design allowed us to consider four stages: pre-dispersed seed, dispersed seed and first year seedling, and the following processes: seed dispersal, seed viability, post-dispersal seed survival, seedling emergence and first year seedling survival. Transition probabilities (TPs) were calculated as the ratio of individuals completing a stage to the number of individuals entering that stage, whilst the overall probability of a dispersed pineseed becoming a live seedling after the first summer was calculated as the product of the successive TPs. Calculations were done separately for every study microhabitat. As a result, we could identify the most influential process in the recruitment dynamics of Pinus nigra (i.e., the process with the lowest transition probability across microhabitats) and the microhabitat most likely to establish regenerates.

The association of Pinus nigra saplings $(0.2 \mathrm{~m}<$ height $<1.3 \mathrm{~m})$ with shrubs, specifically with plants of Juniperus communis, was studied in Puertollano forest. Juniperus communis is a bird-dispersed shrub present in dry shrublands in the circum-Mediterranean mountains. At Puertollano forest, Juniperus communis is common in the understory, together with Berberis hispanica and small cushion-shape shrubs, such as Erinacea anthyllis and Teucrium poleum L. (Table 1). A previous visual estimation indicated that Berberis hispanica does not seem to nurse pine saplings, confirming results from previous research [33]. Similarly, facilitation by small cushion-shape shrubs tends to be of little importance in Mediterranean environments [15]. Therefore, we focused on the potential facilitative effect of Juniperus communis in the establishment of Pinus nigra regenerates [34]. Thus, we counted all Pinus nigra saplings in the eight plots mentioned previously and determined whether they were growing at protected or unprotected sites, i.e., any sapling growing inside or in the vicinity (maximun $\leq 20 \mathrm{~cm}$ 
distance) of a Juniperus communis plant was considered to be protected by the shrub's microclimatic influence, otherwise the sapling was noted as unprotected. For each Pinus nigra sapling classified as protected, we recorded the azimuth quadrant or aspect $(\mathrm{N}, \mathrm{E}, \mathrm{S}$ or $\mathrm{W})$ of its location with respect to the nearest shrub.

\subsection{Statistical Analysis}

Differences between microhabitats in the regeneration stages considered were explored by ANOVAs. Where necessary, data were log-transformed to meet assumptions of parametric statistical analyses [35]. Alternatively, non-parametric tests were used when the assumptions of parametric tests were not met. Concordance across microhabitats in the process of recruitment was explored using TPs values and Kendall coefficients of concordance. The null hypothesis of Pinus nigra sapling distribution being independent of aspect position with respect to Juniperus communis shrubs, was tested by a chi-square test. The contribution of each aspect position to the overall significance was assessed by testing if each observed frequency $(O)$ was significantly different from the frequency expected by chance $(E)$, computing the following statistic:

$$
Z=\frac{|\mathrm{O}-\mathrm{E}|}{\sqrt{\mathrm{O}(1-\mathrm{O} / \mathrm{n})}}
$$

where $n$ is the total number of observations in the contingency table. When statistic $Z$ is larger than the critical value $Z_{[1-(\alpha / 2 \text { no. cells)] }}$ read from a table of normal deviates, $O$ is significantly different from $E$ at the probability level $\alpha / 2$ for a one-tailed test [36]. All analyses were conducted with STATISTICA [37]. Data are reported as means \pm S.D.

\section{Results}

\subsection{Structural Analysis}

Pinus nigra was the dominant tree species in Cañada del Espino forest. It was accompanied by Pinus pinaster Ait., Quercus ilex and Q. faginea, although these three species represented less than 2.6\% of total basal area. Mean density was $355.93 \pm 247.81$ trees ha ${ }^{-1}$, mean basal area $24.30 \pm 15.45 \mathrm{~m}^{2} \mathrm{ha}^{-1}$, and mean volume $171.16 \pm 107.33 \mathrm{~m}^{3} \mathrm{ha}^{-1}$. In Puertollano forest, Pinus nigra was the only tree species present in the sampled plots. Mean density was $159.50 \pm 93.79$ tress $^{-1} \mathrm{a}^{-1}$, mean basal area $16.75 \pm 5.40 \mathrm{~m}^{2} \mathrm{ha}^{-1}$, and mean volume $149.65 \pm 62.06 \mathrm{~m}^{3} \mathrm{ha}^{-1}$.

Tree density differed between the two study forests (Mann-Whitney $\mathrm{W}$ test, $\mathrm{W}=39.5$, $\mathrm{p}$-value $=0.04$ ), as did shrub cover. The more open forest structure found in Puertollano resulted in a higher overall value of shrub cover (Table 1), the percentages of open spaces (not covered by shrubs) being $80.5 \%$ in Cañada del Espino and $29.6 \%$ in Puertollano forest. Tree forest structure was more complex at Puertollano, since all the sampled plots but one showed a very high dbh differentiation $(\mathrm{Cv}>60 \%)$. Dbh differentiation was high $(30 \%<\mathrm{Cv} \leq 60 \%)$ in 13 sampled plots from Cañada del Espino forest, and moderate $(30 \%<\mathrm{Cv} \leq 60 \%)$ in the remaining 7 plots. This difference in forest structure could be partially explained because of the higher number of large trees found in the forest of Puertollano ( $35.5 \pm 19.6$ vs. $12.3 \pm 23.1$ in Cañada del Espino forest). The largest tree sampled in Cañada del 
Espino measured $58 \mathrm{~cm}$, whilst 15.5 trees per hectare were on average above that dbh value at Puertollano. Thus, the latter forest showed the wider range of diameter distribution (Figure 2). Snag density varied between 0 and 20 dead trees $\mathrm{ha}^{-1}$ (mean $4.3 \pm 7.9$ snags ha $^{-1}$ ) in plots from Puertollano forest. All sampled snags attained sizes above $60 \mathrm{~cm}$ dbh. At Cañada del Espino forest, mean density of dead trees was $10.4 \pm 29.6$ snags ha $^{-1}$, with a smaller mean diameter of $20.4 \pm 10.9 \mathrm{~cm}$.

Figure 2. Diameter size distribution from the two study forests. C. del Espino is a management unit within a forest regularly managed over the 20th century. Puertollano can be considered an old-growth patch.

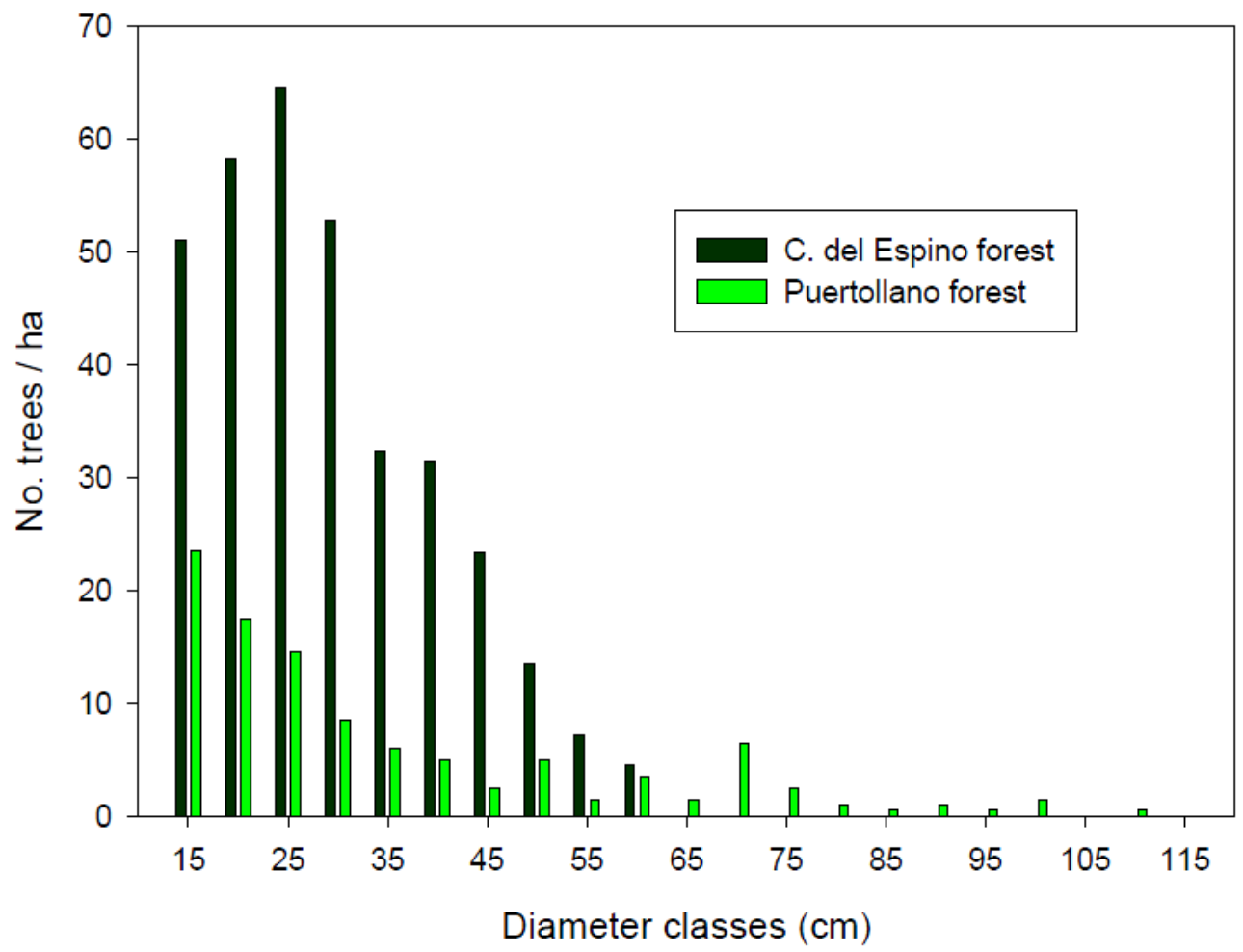

\subsection{Regeneration Patterns}

The mast fruiting of Pinus nigra during the study year resulted in a widespread seed rain over Cañada del Espino forest (mean density $=877 \pm 34 \mathrm{seed}^{-2}$ ). All traps collected seeds (range 6-168) during the dispersal period, although seed density was more homogeneous under dense canopies $(\mathrm{CV}=0.25)$ than in gap microhabitats $(\mathrm{CV}=0.42)$. The mean number of seeds collected by traps differed significantly between stands $\left(\mathrm{F}_{2,69}=28.60\right.$, $\mathrm{p}$-value $\left.<0.0001\right)$, but did not change between microhabitats $\left(\mathrm{F}_{2,23}=1.87\right.$, $\mathrm{p}$-value $=0.1767$; Table 2$)$. Within the total amount of dispersed seeds, all microhabitats received a similar percentage of empty seeds $(<10.86 \pm 1.70 \%$ in the three cases; Kruskal-Wallis test, $\mathrm{p}$-value $=0.270$ ), and a similar percentage of full seeds that did not germinate in the growth chamber $(<2.78 \pm 1.34 \%$ in the three cases; Kruskal-Wallis test, p-value $=0.392)$. 
Table 2. Mean and standard deviates for different demographic parameters in Cañada del Espino forest.

\begin{tabular}{|c|c|c|c|c|}
\hline & $\begin{array}{c}\text { Dispersed } \\
\text { seeds }\left(\text { no. } / \mathbf{m}^{2}\right)\end{array}$ & $\begin{array}{c}\text { Emerged } \\
\text { seedlings }\left(\text { no. } / \mathbf{m}^{2}\right)\end{array}$ & $\begin{array}{l}\text { Seedling survival } \\
\text { after } 45 \text { days (\%) }\end{array}$ & $\begin{array}{l}\text { Seedling survival } \\
\text { after } 100 \text { days (\%) }\end{array}$ \\
\hline \multicolumn{5}{|c|}{ Microhabitat } \\
\hline Gap & $858 \pm 85$ (a) & $460 \pm 47$ (a) & $28.00 \pm 8.10$ & $0.88 \pm 0.64$ \\
\hline Clear forest & $830 \pm 50(a)$ & $694 \pm 73$ (a) & $55.83 \pm 7.39$ & $5.56 \pm 2.55$ \\
\hline Dense forest & $890 \pm 63$ (a) & $588 \pm 102(\mathrm{a})$ & $39.83 \pm 7.39$ & $0.29 \pm 0.29$ \\
\hline \multicolumn{5}{|l|}{ Stand } \\
\hline A & $633 \pm 26(a)$ & $502 \pm 51(\mathrm{a})$ & $39.60 \pm 7.10$ & $0.29 \pm 0.29$ \\
\hline B & $901 \pm 46(b)$ & $600 \pm 49$ (a) & $57.29 \pm 6.48$ & $5.65 \pm 2.14$ \\
\hline $\mathrm{C}$ & $1.098 \pm 54(\mathrm{c})$ & $851 \pm 83(b)$ & $37.08 \pm 6.48$ & $5.45 \pm 2.05$ \\
\hline
\end{tabular}

Different letters indicate significant differences in a Tukey HDS test $(\mathrm{p}<0.05)$.

Overall, $14.93 \pm 0.25 \%$ of the dispersed seeds were predated. This percentage was not correlated with seed density $\left(\mathrm{R}_{\text {Spearman }}=0.156, \mathrm{n}=64, \mathrm{p}\right.$-value $\left.=0.219\right)$, and there were no significant differences between microhabitats (Kruskal-Wallis test, $\mathrm{p}$-value $>0.05$ ).

Germination capability was above $97 \%$ in the growth chamber. Under field conditions, 2082 seedlings emerged in the demographic plots, resulting in a mean density of $616.80 \pm 335.45$ seedlings $\mathrm{m}^{-2}$. Seedling density was similar between microhabitats $\left(\mathrm{F}_{2,23}=1.36\right.$; $\mathrm{p}$-value $\left.=0.2774\right)$, but, as with seed density, stand $\mathrm{C}$ showed a higher seedling density $\left(\mathrm{F}_{2,69}=8.10\right.$, $\mathrm{p}$-value $<0.0001$; Table 2$)$.

More than $99 \%$ of emerged seedlings died over the first growing period, desiccation being noted as the main cause of mortality. Indeed, rainfall was almost nil over the summer season of the study year (5 mm in July, $1.2 \mathrm{~mm}$ in August). Therefore, the major 'bottleneck' in Pinus nigra recruitment dynamics was found to be at the seedling stage, which attained very low transition probabilities in the three study microhabitats (Figure 3), thereby conditioning the cumulative probabilities of recruitment (Figure 4). On the other hand, the highest transition probabilities occurred for seed viability in all three cases, for post-dispersal seed survival in the gap and dense forest microhabitats, and for seedling emergence in the clear forest microhabitat (Figures 3 and 4), but stage-specific transition probabilities did not meet concordance across microhabitats (Kendall Coefficient of Concordance $=0.233$, p-value $<0.247, \mathrm{~N}=6, \mathrm{df}=2$ ). The microhabitat with the best recruitment quality for seedling survival was the clear forest, where 190 of every 10,000 emerged seedlings had survived after their first summer. The worst microhabitat was gap, where all the emerged seedlings died. Finally, 42 saplings of Pinus nigra were located growing inside Juniperus communis shrubs, and another 75 saplings in their vicinity. Aspect locations of Pinus nigra saplings with respect to the nearest shrub were non-uniform $\left(\chi^{2}=14.867\right.$; df $\left.=3 ; \mathrm{p}<0.002\right)$. Pinetree recruitment occurred preferentially towards the north margin of the nearest shrub, where seedlings and saplings were most likely to find protection from both high temperatures and intense solar radiation (Figure 5). 
Figure 3. Diagram of the spatial dynamics of recruitment in each one of the microhabitats considered. Ovals represent the stages and rectangles the processes of recruitment analyzed. Values shown are process-specific transition probabilities (TPs). OPR represents the overall probability of recruitment at each microhabitat. $\mathrm{D}=$ seed dispersal; $\mathrm{V}=$ seed viability; $\mathrm{S}_{\mathrm{s}}=$ post-dispersal seed survival; $\mathrm{E}=$ seedling emergence; $\mathrm{SD}_{\mathrm{s}}=$ seedling survival.

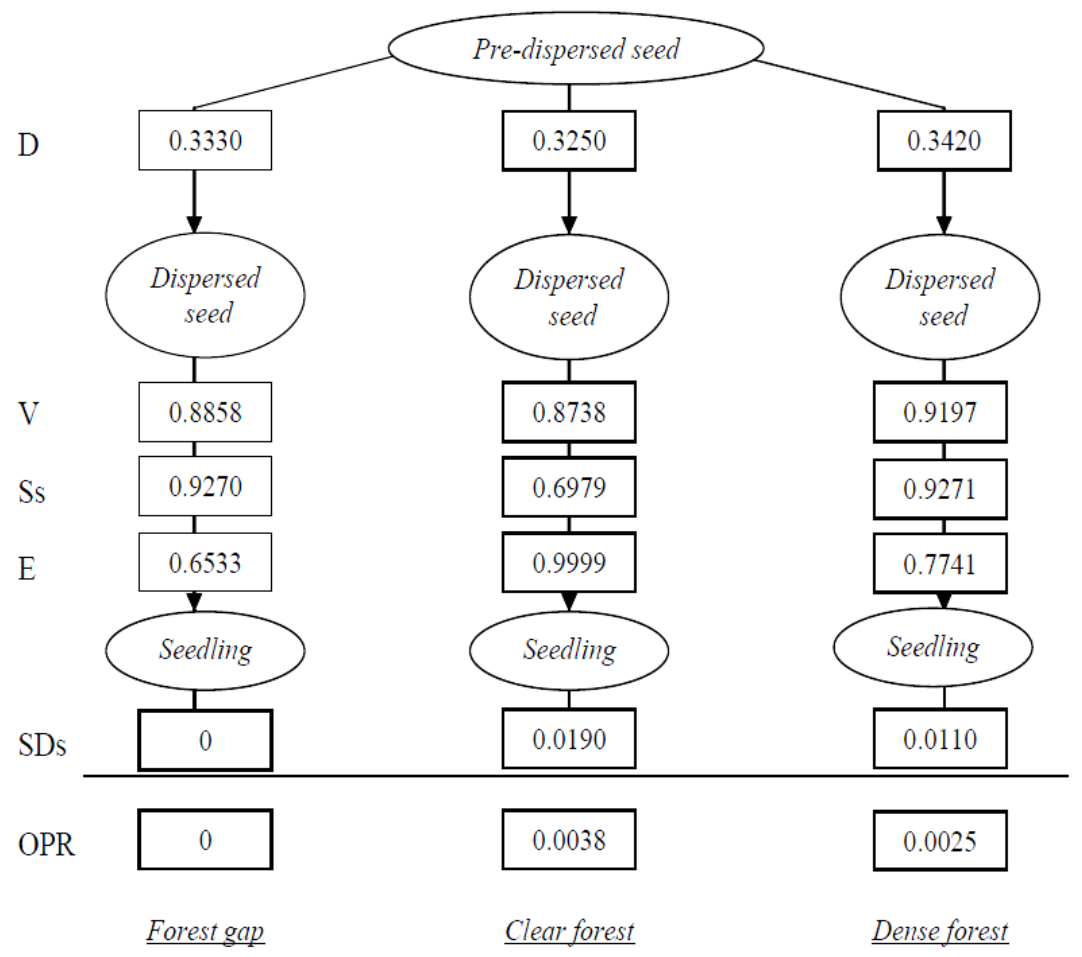

Figure 4. Cumulative probability of recruitment of Pinus nigra throughout the different recruitment stages. R, pre-dispersal seed (arbitrarily assigned the value 1); D = seed dispersal; $\mathrm{V}=$ seed viability; $\mathrm{S}_{\mathrm{s}}=$ post-dispersal seed survival; $\mathrm{E}=$ seedling emergence; $\mathrm{SD}_{\mathrm{s}}=$ seedling survival.

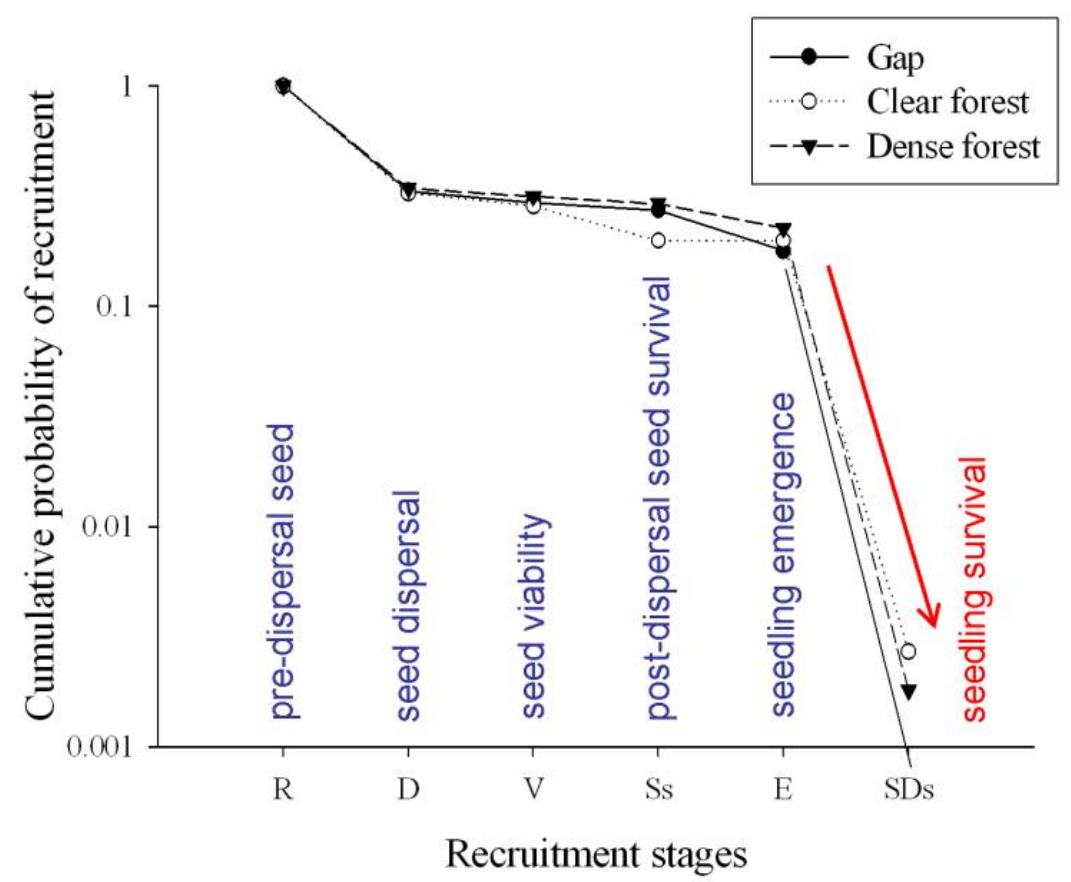


Figure 5. Observed and expected aspect orientation of Pinus nigra saplings with respect to nearest Juniperus communis shrubs. * indicates significant differences $(\mathrm{p}<0.001)$.

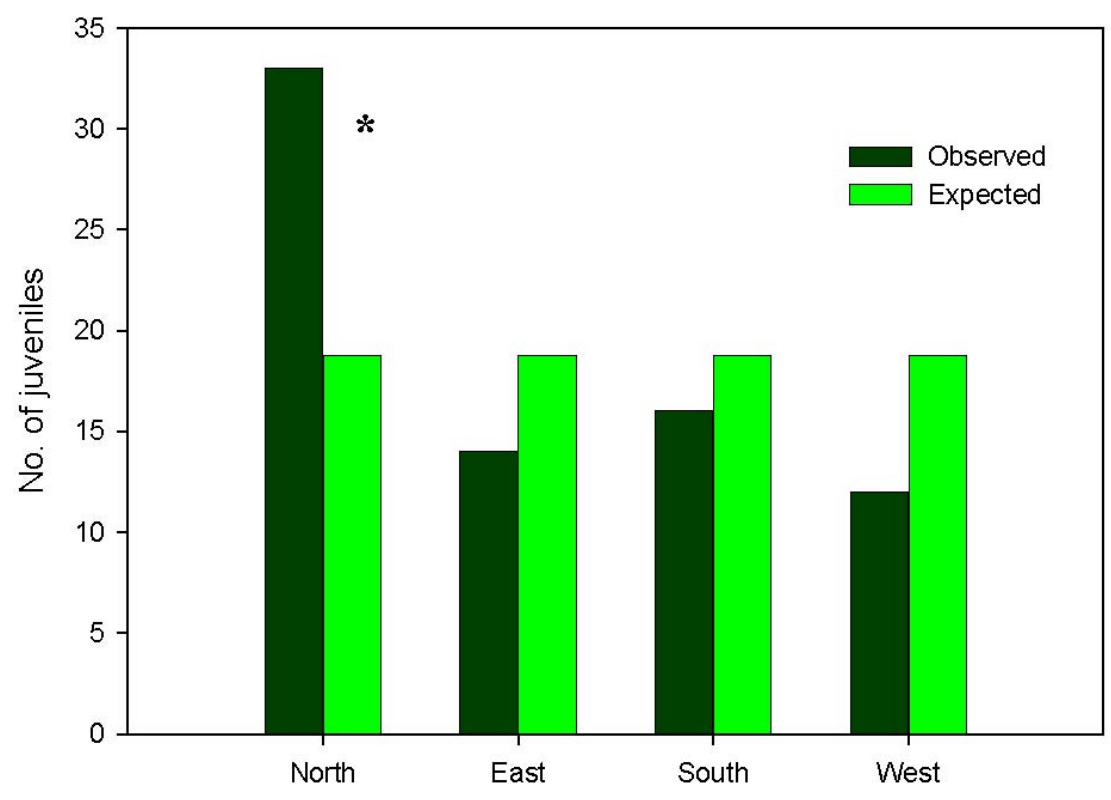

\section{Discussion}

Conclusions from this study will be clearly limited by the temporal and spatial scales of the research. Yet, we present here a first attempt to understand the functioning of Pinus nigra forests from the southernmost limit of the species' natural range, an area highly exposed to the loss of tree species due to climate change [26]. Beyond general reviews of the potential effects of climate change on forest ecosystems, some understanding about the structure and function of target forests should be gathered before developing actions to accommodate forest management to changing climates $[5,20,38]$. This may be particularly important in mountainous and/or marginal populations, because of the great diversity of mechanisms and processes they exhibit [6]. Structure and regeneration patterns of Pinus nigra at the southern margin of the species range were analyzed in this research.

\subsection{Forest Structure}

Current structure of the two study forests proved to be a result of their past. Management imposes a rotation age and limits the maximun age (and size) that a tree can reach. Therefore, fewer trees attained large dimensions in the managed forest of Cañada del Espino compared with the less influenced area of Puertollano. Large and veteran trees are a valuable resource for biodiversity [39]. For instance, veteran individuals of Pinus nigra show a distinctive architecture that might provide biodiversity with types of habitat different from those offered by younger trees, but little is known in this respect. As far as we are aware, the only existing information refers to the importance of large pines as primary sources of deadwood, because the survival of some endangered saproxilic beetles from the study area depends on the availability of large snags and logs [40].

In addition to the number of large trees, mean dbh and the standard deviation of tree dbh have been used as measurements of structural complexity. The latter correlates significantly with several indices of structural complexity, and is considered indicative of the diversity of micro-habitats within a stand [31], 
but it depends on the mean and the units of measurement. Instead, we preferred to use the coefficient of variation, i.e., the ratio of the standard deviation to the mean, in order to facilitate the comparison of structural complexity between the two study forests. Results showed that Puertollano attained the highest structural diversity in comparison with the more intensively managed area of Cañada del Espino. Studies of plant, avian and insect diversity generally show that structural diversity can indicate overall species diversity [41]. Information from Puertollano forest could then serve as a guide for the development of silvicultural practices aimed to maintain biodiversity in other Pinus nigra stands. Among other reasons, because the aim of maintaining biodiversity coincides with strategies to increase the resistance and resilience of forests to climate change [3,5].

Deadwood was concentrated in large snags at Puertollano forests, representing $15 \%$ of the overall standing volume. This was four times the deadwood volume observed in Cañada del Espino, where deadwood came from thinner trees that had been broken or uprooted by strong winds or heavy snowfalls. According to forest inventory data, these types of minor disturbances are frequent in the study area. However, the return frequency of major or stand-replacing disturbances, such as naturally ignited fires, is well above 200 years [42].

Shrub cover was another structural component that differed between the two study forests. The forest overstory-understory relationship is complex and two-sided, but is nonetheless dominated by the strong influence of the overstory composition and structure through both its effects on the litter and light quantity and quality [43]. Thus, percentage differences in shrub cover between the two study sites were likely reflecting differences in canopy cover, i.e., Puertollano forest attained higher shrub cover because the forest canopy was more open there than in Cañada del Espino.

\subsection{Regeneration Patterns}

Seed production by Pinus nigra exhibits several characteristics of mast-fruiting plants, including supra-annual synchrony and irregular fruiting intervals [24]. Masting may represent an evolved response to seed predation ("predator satiation hypothesis" [44]). In this respect, seed predators (mostly Apodemus sylvaticus) caused $15 \%$ of losses of dispersed seeds during the last year reported here. This result is far below the predation rates found in a nearby Pinus sylvestris pinewood [45]. On the other hand, the three study microhabitats received a similar, considerable amount of sound seeds able to germinate, indicating that seed production and dispersal are efficient in Pinus nigra forests (Table 2), and that recruitment failure is not determined in the long-term by seed availability. Alternatively, Pinus nigra recruitment could be limited by specific environmental requirements. In this respect, desiccation at the seedling stage proved to represent the major 'bottleneck' of Pinus nigra demography, so variation in soil temperature and moisture content can be crucial for the species recruitment.

Results from this study suggest that small scale heterogeneity influences seedling emergence, clear forest microhabitat offering the most favorable conditions for seed germination $(\mathrm{TP} \sim 1)$ and gap microhabitat the worst ( $\mathrm{TP}=0.6533$ ). Similarly, clear forest microhabitat attained the highest seedling survival, while gap microhabitat showed the lowest performance (Figure 3). Small scale heterogeneity can be the result of variations in microclimate and soil moisture [8]. Canopy cover is known to offer protection against temperature extremes and excessive evapotranspiration [14], although drought might be increasingly harmful under shadier conditions because water absorption and light capture cannot be 
maximized simultaneously [46]. Therefore, an intermediate percentage of canopy cover, such as that observed in clear forest microhabitats, can represent a solution for a light availability-water status trade-off. The reported association between Juniperus communis shrubs and juveniles of Pinus nigra supports that prediction. Thus, these canopy- or shrub- facilitation effects may play a key role in new climate scenarios of longer and hotter summers.

Obviously, any generalization made from the results obtained in this study should be taken with caution, because data were collected during a single reproductive event (one year). However, it is well established in the literature that Pinus nigra produces irregular seed crops [24], and that desiccation is a major cause of seedling mortality among Mediterranean tree species $[8,11,16]$. Therefore, the conclusions reported here are likely to fit well with the reality of Pinus nigra forests at larger spatial and temporal scales.

\subsection{Implications for Management}

It can reasonably be predicted that most Pinus nigra stands will exhibit an open forest structure in the future because of failed regeneration and high tree mortality in a drying environment. Here, we have shown that desiccation is the major cause of mortality at the early stages of seedling establishment, and different papers have already reported high tree mortality due to uncommonly warm dry conditions across the Mediterranean region, including pine forests from the eastern mountains of Spain [47]. Moreover, tree mortality associated with climate stress can be exacerbated by tree-to-tree competition in dense Mediterranean forests, resulting in a significant diminution of tree density [48,49]. The current structure of Puertollano may closely represent the expected physiognomy of future Pinus nigra forests, i.e., clear stands with an open canopy and a dense drought-adapted understory of different shrub species. Thus, understory cover should increase beneath a more open forest canopy [43], but the role of shrubs in favoring Pinus nigra regeneration will depend on both species identity and shrub capacity to colonize new areas.

Results from this study show that Juniperus communis is a suitable nurse shrub that facilitates Pinus nigra establishment in natural forests, while other species, such as Berberis hispanica and small pioneer shrubs (Erinacea anthyllis and Teucrium poleum), do not. Siles et al. [33] obtained similar results in their study on facilitation, and added Juniperus oxycedrus L. and Pistacia terebinthus L. to a list of species native to the study area that could be used as nurse shrubs. However, the probability that a pine forest is colonized by a new shrub species depends on the location and composition of nearby vegetation, and some sort of human intervention may be necessary [50,51]. Clearly, managers of Mediterranean forests will need to know as much about shrub ecology as they already know about the ecology of commercial tree species.

Garden experiments have shown that seedlings of Pinus nigra do not exhibit photoinhibition problems [52], but they tend to establish in stands of intermediate canopy cover under natural conditions [14]. This indicates the existence of facilitative interactions in which the negative effects of light scarcity would be outweighed by an improvement of the seedling water status. A seedling-canopy interaction that resembles the seedling-shrub interaction already commented. We similarly found higher seedling survival in the clear forest microhabitat (40-60\% canopy cover), so stands with 
intermediate values of canopy cover likely offer a compromise between the light and the soil moisture that Pinus nigra seedlings need to establish in the understory.

In summary, both tree canopies and shrubs can facilitate the establishment of Pinus nigra regenerates, so these forests should be managed considering facilitative interactions. Probably, close-to-nature forestry offers the best operational way to do so in a context of adaptive management, and could improve the adaptive capacity of Pinus nigra forests under expected climate change scenarios. The principles of close-to-nature forestry have been commented elsewhere [22,24,53]. Briefly, close-to-nature management is based on the treatment of individual trees, taking into account the economic and ecological functions performed by trees at the stand level. In close-to-nature management, harvest operations are restricted to trees of sufficient diameter that have already attained their maximum economic value (timber of good quality) for the species and site. Thus, a tree will remain in the stand if it continues to increase its market price and/or it is favoring the accumulation of value in other trees (productive function) or benefitting biodiversity. Trees can develop productive functions alone, or by the improvement of adjacent trees (e.g., favoring natural pruning and shelf-thinning processes). Benefits for biodiversity involve the conservation of rare tree species, the maintenance of dead and decaying trees and the provision of nesting holes for birds, etc. A significant aspect of close-to-nature management is that the felling of trees is not affected by the desire to achieve a balanced age-class distribution (a normal forest), rather trees are felled according to their own vitality. This offers a better opportunity to recreate the evolutionary environment of Pinus nigra forests whilst harvesting their resources, and let accommodate episodic regeneration into the management schedule (see latter), for example, recruitment after unpredictable rainy summers [54]. The method is also flexible enough to easily accommodate modifications, in order to implement an adaptive forest management strategy to cope with climate change.

Managers have traditionally relied on naturally dispersed seeds to regenerate Pinus nigra forests from Cazorla, Segura and Las Villas Natural Park, having resorted to artificial regeneration only to restore degraded sites. However, the planting of seedlings properly nurtured at nurseries is likely to be of greater importance in the near future under a drying climate. In this respect, the role of facilitative interactions will be important for artificial regeneration as well [55], but whether planting is more important than natural regeneration for the maintenance of Pinus nigra forests in the coming years will depend on economic and ecological constrains.

If the felling of Pinus nigra is still profitable in a global timber market, artificial regeneration will be necessary to keep up with the current rotation period of harvesting operations.If, however, the maintenance of biodiversity and other ecosystem services are to prevail over wood production, or the latter is no longer profitable, it will be possible to wait for the natural establishment of new trees (rate establishment is expected to be slower under drier conditions), because Pinus nigra is a very long-lived species and episodic recruitment is expected to occur in years of favorable weather [54]. Our opinion is that natural regeneration should always be the first management option, amongst other reasons, because it will let natural selection act and will result in trees well adapted to the site. It seems clear that silviculture practices will need to consider facilitative interactions in order to regenerate naturally the study forests, but uncertainties about the effect of climate change will need to be solved through a process of adaptive management. 


\section{Acknowledgements}

Consejería de Medio Ambiente, Junta de Andalucía (Spain) provided the means for carrying out the research.

\section{Conflict of Interest}

The authors declare no conflict of interest.

\section{References}

1. Lovelock, J. The Revenge of Gaia; Penguin Books: London, UK, 2006; p. 175.

2. IPCC. Climate Change, Fourth Assessment Report; Cambridge University Press: London, UK, 2007; p. 255.

3. Millar, C.I.; Stephenson, N.L.; Stephens, S.L. Climate change and forests of the future: Managing in the face of uncertainty. Ecol. Appl. 2007, 17, 2145-2151.

4. Linares, J.C.; Tíscar, P.A. Climate change impacts and vulnerabilitity of the southern populations of Pinus nigra subsp. salzmannii. Tree Physiol. 2010, 30, 795-806.

5. Noss, R.F. Beyond Kyoto: Forest management in a time of rapid climate change. Conserv. Biol. 2001, 15, 578-590.

6. Hampe, A.; Jump, A.S. Climate relicts: Past, present, future. Annu. Rev. Ecol. Evol. Syst. 2011, 42, 313-333.

7. Herrera, C.M. Topsoil properties and seedling recruitment in Lavandula latifolia: Stage-dependence and spatial decoupling of incluential parameters. Oikos 2002, 97, 260-270.

8. Gómez-Aparicio, L. Spatial patterns of recruitment in Mediterranean plant species: Linking the fate of seeds, seedlings and saplings in heterogeneous landscapes at different scales. J. Ecol. 2008, 96, 1128-1140.

9. Linares, J.C.; Carreira, J.A.; Ochoa, V. Human impacts drive forest structure and diversity. Insights from Mediterranean mountain forest dominated by Abies pinsapo (Boiss.). Eur. J. Forest Res. 2011, 130, 533-542.

10. Linares, J.C.; Tíscar, P.A.; Camarero, J.J.; Taïqui, L.; Viñegla, B.; Seco, J.I.; Merino, J.; Carreira, J.A. Tree growth decline on relict Western-Mediterranean mountain forests: Causes and impacts. In Forest Decline: Causes and Impacts; Jenkins, J.A., Ed.; Nova Science Publishers Inc.: Hauppauge, NY, USA, 2011.

11. Rey, P.J.; Alcántara, J. Recruitment dynamics of a fleshy-fruited plant (Olea europaea): Connecting patterns of seed dispersal to seedling establishment. J. Ecol. 2000, 88, 622-633.

12. Rees, M.; Mangel, M.; Turnbull, L.; Sheppard, A.; Briese, D. The effects of heterogeneity on dispersal and colonization in plants. In The Ecological Consequences of Enrironmental Heterogeneity; Hutchings, M.J., John, E.A., Stewart, A.J.A., Eds.; Blackwell Science: Oxford, UK, 2000; pp. 237-266.

13. Puerta-Piñero, C.; Gómez, J.M.; Valladares, F. Irradiance and oak seedling survival and growth in a heterogeneous environment. Forest Ecol. Manag. 2007, 242, 462-469. 
14. Gómez-Aparicio, L.; Zavala, M.A.; Bonet, F.J.; Zamora, R. Are pine plantations valid tools for restoring Mediterranean forests? An assessment along abiotic and biotic gradients. Ecol. Appl. 2009, 19, 2124-2141.

15. Gómez-Aparicio, L.; Zamora, R.; Gómez, J.M.; Hódar, J.A.; Castro, J.; Baraza, E. Applying plant facilitation to forest restoration: A meta-analysis of the use of shrubs as nurse plants. Ecol. Appl. 2004, 14, 1128-1138.

16. Herrera, C.M.; Jordano, P.; López-Soria, L.; Amat, J.A. Recruitment of a mast-fruiting, bird-dispersed tree: Bridging frugivore activity and seedling establishment. Ecol. Monogr. 1994, 64, 315-344.

17. Lindner, M.; Maroschek, M.; Netherer, S.; Kremer, A.; Barbati, A.; Garcia-Gonzalo, J.; Seidl, R.; Delzon, S.; Corona, P.; Kolström, M. Climate change impacts, adaptive capacity, and vulnerability of European forest ecosystems. Forest Ecol. Manag. 2010, 259, 698-709.

18. Smith, D.M.; Larson, B.C.; Kelty, M.J.; Ashton, P.M.S. The Practice of Silviculture: Applied Forest Ecology; Wiley: New York, NY, USA, 1997.

19. Stephens, S.L.; Millar, C.I.; Collins, B.M. Operational approaches to managing forests of the future in Mediterranean regions within a context of changing climates. Environ. Res. Lett. 2010, 5, 024003.

20. Spittlehouse, D.L.; Stewart, R.B. Adaptation to climate change in forest management. BC $J$. Ecosyst. Manag. 2003, 1, 1-11.

21. Drever, C.R.; Peterson, G.; Messier, C.; Bergeron, Y.; Flannigan, M. Can forest management based on natural disturbances maintain ecological resilience? Can. J. Forest Res. 2006, 36, 2285-2299.

22. Martín-Fernández, S.; García-Abril, A. Optimisation of spatial allocation of forestry activities within a forest stand. Comput. Electron. Agric. 2005, 49, 159-174.

23. Cayuela, L.; Hódar, J.A.; Zamora, R. Is insecticide spraying a viable and cost-efficient management practice to control pine processionary moth in Mediterranean woodlands? Forest Ecol. Manag. 2011, 261, 1732-1737.

24. Tíscar, P.A.; Linares, J.C. Pinus nigra subsp. Salzmannii forests from Southeast Spain: Using structure and process information to guide management. In Pine forests: Types, Threats and Management; Frisiras, C.T., Ed.; Nova Science Publishers Inc.: Hauppauge, NY, USA, 2011.

25. Richter, K.; Eckstein, D. The dendrochronological signal of pine trees (Pinus sp.) in Spain. Tree-Ring Bull. 1991, 51, 1-13.

26. Linares, J.C.; Tíscar, P.A. Buffered climate change effects in a Mediterranean pine species: Range limit implications from a tree-ring study. Oecologia 2011, 167, 847-859.

27. Sánchez de Medina, A.; García-Abril, A.; Grande, M.A. Los Pinares de Pinus nigra Arn. en España. In Los Pinares de Pinus Nigra Arn. en España: Ecología, uso y Gestión; García-Abril, A., Grande, M.A., Eds.; Fundación Conde del Valle de Salazar: Madrid, Spain, 2005; pp. 1-54.

28. Tapias, R.; Climent, J.; Pardos, J.A.; Gil, L. Life histories of Mediterranean pines. Plant Ecol. 2004, 171, 53-68.

29. Lucas-Borja, M.E.; Fonseca, T.; Parresol, B.R.; Silva-Santos, P.; García-Morote, F.A.; Tíscar, P.A. Modeling Spanish black pine seedling emergence: Establishing management strategies for endangered forest areas. Forest Ecol. Manag. 2011, 262, 195-202. 
30. Alejano, R.; Martínez, E. Distribución de Pinus nigra Arn. subsp. salzmannii en las sierras Béticas. Ecología 1996, 10, 231-241.

31. McElhinny, C.; Gibbons, P.; Brack, C.; Bauhus, J. Forest and woodland stand structural complexity: Its definition and measurement. Forest Ecol. Manag. 2005, 218, 1-24.

32. Tíscar, P.A. Capacidad reproductiva de Pinus nigra subsp. salzmannii en relación con la edad de la planta madre. Investig. Agrar. Sist. Recur. Forest. 2002, 11, 357-371.

33. Siles, G.; Rey, P.J.; Alcántara, J.M.; Ramírez, J.M. Assessing the long-term contribution of nurse plants to restoration of Mediterranean forests through Markovian models. J. Appl. Ecol. 2008, 45, 1790-1798.

34. Tíscar, P.A. Condicionantes y limitaciones de la regeneración natural en un pinar oromediterráneo de Pinus nigra subsp. salzmannii. Investig. Agrar. Sist. Recur. Forest. 2003, 12, 55-64.

35. Zar, J.H. Biostatistical Analysis; Prentice Hall Inc.: Englewood Cliffs, NJ, USA, 1984; p. 600.

36. Legendre, P.; Legendre, L. Numerical Ecology; Elsevier: Amsterdam, The Netherlands, 1998.

37. STATISTICA for Windows [Computer Program Manual]; StatSoft, Inc.: Tulsa, OK, USA, 1999.

38. Adaptation of Forests and People to Climate Change-A Global Assesment Report; Seppäla, R., Buck, A., Katila, P., Eds.; IUFRO World: Vienna, Austria, 2009; Volume 22, p. 224.

39. Franklin, J.F.; Spies, T.A.; van Pelt, R.; Carey, A.B.; Thornburgh, D.A.; Berg, D.R.; Lindenmayer, D.B.; Harmon, M.E.; Keeton, W.S.; Shaw, D.C.; Bible, K.; Chen, J. Disturbances and structural development of natural forest ecosystems with silvicultural implications, using douglas-fir forests as an example. Forest Ecol. Manag. 2002, 155, 399-423.

40. Molino, F. Los Coleópteros Saproxílicos de Andalucía. PhD Dissertation, University of Granada, Granada, Spain, 1996.

41. Staudhammer, C.L.; LeMAY, V.M. Introduction and evaluation of possible indices of stand structural diversity. Can. J. Forest Res. 2001, 31, 1105-1115.

42. López-Soria, L.; Castell, C. Comparative genet survival after fire in woody Mediterranean species. Oecologia 1992, 91, 493-499.

43. Coll, L.; González-Olabarria, R.; Mola-Yudego, B.; Pukkala, T.; Messier, C. Predicting understory máximum shrubs cover using altitude and overstory basal área in different Mediterranean forests. Eur. J. Forest Res. 2011, 130, 55-65.

44. Herrera, C.M.; Jordano, P.; Guitián, J.; Traveset, A. Annual variability in seed production by woody plants and the masting concept: Reassessment of principles and relationship to pollination and seed dispersal. Am. Nat. 1998, 152, 576-594.

45. Castro, J.; Gómez, J.M.; García, D.; Zamora, R.; Hódar, J.A. Seed predation and dispersal in relict Scots pine forests in southern Spain. Plant Ecol. 1999, 145, 115-123.

46. Sánchez-Gómez, D.; Valladares, F.; Zavala, M.A. Performance of seedlings of Mediterranean woody species under experimental gradients of irradiance and water availability: Trade-offs and evidence for niche differentiation. New Phystol. 2006, 170, 795-806.

47. Allen, C.D.; Macalady, A.K.; Chenchouni, H.; Bachelet, D.; McDowell, N.; Vennetier, M.; Kitzberger, T.; Rigling, A.; Breshears, D.D.; Hogg, E.H.T. A global overview of drought and heat-induced tree mortality reveals emerging climate change risks for forests. Forest Ecol. Manag. 2010, 259, 660-684. 
48. Linares, J.C.; Camarero, J.J.; Carreira, J.A. Competition modulates the adaptation capacity of forests to climatic stress: Insights from recent growth decline and death in relict stands of the Mediterranean fir Abies pinsapo. J. Ecol. 2010, 98, 592-603.

49. Linares, J.C.; Camarero, J.J.; Carreira, J.A. Interacting effects of changes in climate and forest cover on mortality and growth of the southernmost European fir forests. Glob. Ecol. Biogeogr. 2009, 18, 485-497.

50. Zamora, R.; Hódar, J.A.; Matías, L.; Mendoza, I. Positive adjacency effects mediated by seed disperser birds in pine plantations. Ecol. Appl. 2010, 20, 1053-1060.

51. Matías, L.; Zamora, R.; Mendoza, I.; Hódar, J.A. Seed dispersal patterns by large frugivorous mammals in a degraded mosaic landscape. Restor. Ecol. 2010, 18, 619-627.

52. Gómez-Aparicio, L.; Valladares, F.; Zamora, R. Differential light responses of Mediterranean tree saplings: Linking ecophysiology with regeneration niche in four co-ocurring species. Tree Physiol. 2006, 26, 947-958.

53. Schütz, J. Opportunities and strategies of transforming regular forests to irregular forests. Forest Ecol. Manag. 2001, 151, 87-94.

54. Mendoza, I.; Zamora, R.; Castro, J. A seeding experiment for testing tree-community recruitment under variable environments: Implications for forest regeneration and conservation in Mediterranean habitats. Biol. Conserv. 2009, 149, 1491-1499.

55. Castro, J.; Zamora, R.; Hódar, J.A.; Gómez, J.M. Use of shrubs as nurse plants: A new technique for reforestation in Mediterranean mountains. Restor. Ecol. 2002, 10, 297-305.

(C) 2011 by the authors; licensee MDPI, Basel, Switzerland. This article is an open access article distributed under the terms and conditions of the Creative Commons Attribution license (http://creativecommons.org/licenses/by/3.0/). 